In the middle chapters, the authors survey other processes which have been considered (and in some cases developed) for the separation of heavy nuclides from fission products. The range covered is sufficient to indicate the amazing volume of research which has been carried out on both sides of the Atlantic in this field-ion-exchange separations, metal distillations, halide volatilizations, extractions by molten metals, purification by slagging processes, extraction by fused chlorides as well as the more conventional (and historically important) processes of separation by precipitation.

There is also a section in the book dealing with the disposal of effluents and fission product recovery, a field which has received much attention from authors, both knowledgeable and otherwise, in recent years. It is sufficient to say that the treatment here is brief and chemically factual and scores on both these counts.

A criticism which may be advanced, perhaps, is that the reader is not given very clearly to understand which are the most important separation processes described. The dominant position now held by solvent extraction processes and the resultant commercial difficulties in the way of any competing technology are not brought out very fully. But such an appreciation is not necessarily a function of this book; it is abundantly clear that it represents a valuable and important contribution to chemical literature. It should find its way not only to those science and engineering graduates with some acquaintance of nuclear reactor development but also to that much wider reading public of chemists and chemical engineers who would like to read and have by them an authoritative and interesting work on the applied chemistry of nuclear power. J. E. LITTLECHILD

\section{FOOD ANALYSIS}

The Chemical Analysis of Foods and Food Products By Dr. Morris B. Jacobs. Third edition. Pp. xxiv + 970. (Princeton, N.J.: D. Van Nostrand Company, Inc. ; London: D. Van Nostrand Company, Ltd., 1958.) 103s. 6d.

THE 970 pages of this book include more material than the title indicates. The text includes information on the make-up of several types of food. For example, the chapter on sugar foods and carbohydrates begins with a useful summary of the types of carbohydrates found in foods; the chapter on meat gives definitions of meat products and tables of typical compositions; the chapter on oils and fats contains in tabular form information on 24 fatty acids; the chapter on quality measurement includes a general introduction on flavour acceptance ; while the chapter on milk comprises more than a hundred pages and includes detailed information on composition, on cheese and other products, and on adulterants.

Essentially, however, the work is a practical book for use at the bench. The book begins by describing general chemical and physical methods that are used in the analyses of food products. Directions are given for analysing constituents of all common and given for common foods. The book also includes chapters on undesirable materials in food. For example, one chapter deals with filth, and includes working directions for estimating the amount of rodent excreta, maggots, rancidity, and decomposition in fish and other foods. There are also chapters on pesticide residues, radiochemical determinations, food poisoning and preservatives. The detection of horse meat in presence of other animal tissues is discussed. Chapters are included on artificial sweetening agents and on colouring matters. Instructions are even given for such details as how to count the pits in preserved cherries from which the pits have ostensibly been removed.

In a few respects-for example, in spectrophotometry, in absence of mention of methyl cellulose, in determination of tocopherols and of carotene, in lack of reference to paper chromatography-the book is not up to date, but it would be impossible for so large a work to be kept up-to-the-minute by one author. The book has been produced in the United States and is primarily concerned with codes of practice and food laws in that country, but in nearly all cases the information has general application. The book is indeed a useful compilation.

\section{V. Н. Воотн}

\section{A FLORA OF THE ARCTIC}

\section{Circumpo'ar Arctic Flora}

By Nicholas Polunin. Pp. xxviii +514. (Oxford: Clarendon Press ; London : Oxford University Press, 1959.) 126s. net.

7 WO problems immediately confront those who write on arctic plants : first, the difficulty of defining the limits of what one proposes to term "the Arctic', and secondly, the even greater difficulty of providing an adequate and up-to-date account of that vast and virtually inaccessible area lying east of Finland and west of the Bering straits. Dr. Polunin with his extensive experience of the arctic and arctic vegetation faces up boldly to the first problem and can no doubt furnish weighty arguments in favour of what appears to be a curiously involved, indeed almost tortuous, delimitation. As regards the second problem, the author freely admits that our knowledge of the Soviet arctic is inadequate, and that, in present circumstances, no Western or American botanist can hope to compile a detailed and critical circumpolar flora. Some may foel, this being so, that any attempt to deal with the flora of the area is bound to be premature and unsatisfactory. The number of flowering plants and vascular cryptogams occurring in the Arctic is so small that the critic has some right to expect a minute and detailed anaiysis, and to be more exacting in his demands than if the author were attempting a survey of some tropical region with a richly diversified flora. If the reader approaches Dr. Polunin's book in this frame of mind he will find much to criticize, for the very frequent use of the tell-tale abbreviations agg. and s.l. after the scientific names shows how much has still to be done before the last word can be written on this subject. But half a loaf is better than no bread, and the less exacting will be glad that Dr. Polunin has had the energy and enterprise to give us a concise, lavishly illustrated and, for practical purposes, a tolerably complete account of these northern plants.

British botanists, whose thoughts turn not infrequently to those epochs when much of Great Britain lay buried under ice and snow, will be intrigued to see how many truly arctic species still survive from those bygone glaciations, and (bearing in mind recent, 